\title{
Examining the Antecedents to Inter-partner Credible Threat in the International Joint Ventures
}

\author{
Lan-Ying Huang \\ Department of Business Administration \\ National Changhua University of Education, Changhua 500, Taiwan, R.O.C. \\ Tel: 88-64-7232105 ext. 7348 E-mail: lyh@cc.ncue.edu.tw
}

Ying-Jiun Hsieh (Corresponding author)

Institute of Technology Management

National Chung Hsing University, Taichung 402, Taiwan, R.O.C.

Tel: 88-64-22840547 ext. 829 E-mail: arborfish@nchu.edu.tw

Pei-Ling Hsiao

Feng Tay Enterprises Co., Ltd., Yunlin County 640, Taiwan, R.O.C.

\author{
Received: August 18, 2011 \\ Accepted: September 6, 2011 Published: January 1, 2012 \\ doi:10.5539/ibr.v5n1p49 \\ URL: http://dx.doi.org/10.5539/ibr.v5n1p49
}

\begin{abstract}
Since the 1980s, international joint venture (IJV) becomes a strategic tool enabling firms to escape from operational risk and cost. However, the IJV represents a voluntary cooperative relationship between partners; it is prone to risk of opportunistic behavior by one or both partners in this relationship. Therefore, some characteristics of the IJV are unstable and difficult to manage. Essentially, the inter-partner credible threat entails the certainty of a firm's retaliation given its partner's earlier cheating. This study explores the antecedents to inter-partner credible threat. The study develops an integrative framework to explain how economic mechanisms, business expertise, and relationship mechanisms affect the partner's relative credible threat. The authors use 40 Taiwanese companies which engage in IJV activities as the sample and the returns-ratio is $12.41 \%$. Evidence explores that the more in the investment size, technological capabilities and low dependency of the partner, this partner exerts more credible threat to the other partner.
\end{abstract}

Keywords: Credible threat, International joint ventures, Opportunistic behavior

\section{Introduction}

Since the 1980s, international joint ventures (IJV) have grown rapidly as a proliferating form of foreign direct investment (Beamish \& Jung, 2005). IJVs have been used in emerging countries as an organizational response that enables foreign partners escape from environment uncertainty in general, and from country risk in particular (Meschi, 2005). Steensma and Lyles (2000) also described joint ventures with local firms are commonly used by multinationals as a means to navigate those uncertain yet high-potential transitioning market. However, the IJV has sometimes been described as unstable (Yan \& Zang, 1999; Kaufmann, O'Neil \& York, 2006), prone to high rates of early termination (Pearce, 1997) and difficult to manage (Madhok, 2006). One of the main reasons comes from partners' opportunism, which is the central concept in the study of hybrid governance structures (Williamson, 1991). Because the IJV represents a voluntary cooperative relationship between partners, it is prone to risk of opportunistic behavior by one or both partners in this relationship (Parkhe, 1993). Therefore, IJVs are highly susceptible to opportunistic behavior generated by costly sub goal pursuits. It makes investors to spend time and efforts to avoid and prevent such behaviors, not because all economic agents behave opportunistically all the time, but because "some agents behave in this fashion and it is costly to sort out those who are opportunistic from those who are not" (Williamson, 1985). Willamson (1985) noted that if opportunism is absent in alliances, it would suffice for parties to always agree to adapt to unanticipated contingencies in a jointly optimal way and always to share profits according to some general rules established in advance. Namely, the existence of opportunism is unavoidable. 
Due to the existence of opportunism and instability of IJVs, several approaches are proposed to make partners cooperative; one of them is the invisible-hand approach (Friedman \& Hechter, 1990). It is argued that the emergence of cooperation comes from spontaneous and voluntary actions of partners who share no common ends or values. Cooperation persists because it constitutes a self-enforcing equilibrium. Zhang and Rajagopalan (2002) argued that when self-enforcing equilibrium exists, partners do not have to control the alliances and they will stick to cooperation. They proposed the role of inter-partner credible threat, which means "the certainty of either partner's retaliation given the other partner's earlier cheating." Zhang and Rajagopalan (2002) concluded that when inter-partner credible threat exists in the IJV, partners can even prevent others' opportunistic behavioral without superfluous control. They further pointed out that inter-partner credible threat is the first order determinant of partners' relative payoffs, and partners' relative control is the second one. Kaufmann, O'Neil and York (2006) also indicated that the credible threat can reach extra-transactional dealings, decrease partners' bad behaviors and increase the likelihood of IJVs' survival.

Prior research only discussed the situations whether IJV partners can exert credible threat or not (Zhang \& Rajagopalan, 2002; Kaufmann, O'Neil \& York, 2006; Duan \& Juma, 2007). This study argues that the exertion of credible threat is not absolute but rather varies with its sources. However, scholars have argued that resources between partners may not always balance (Yan \& Gray, 1994) and the degree of partners' capabilities may vary (Lane, Salk \& Lyles, 2001). Therefore, partners' relative resources and capacities may result in their relative credible threat. It is worth to know the determinants of the source of partners' relative credible threat and discuss if asymmetric source would cause asymmetric credible threat. This study provides an integrative framework to explore the antecedents, which include economic mechanism, organizational capabilities and the relationship mechanism between partners, to inter-partner credible threat in the IJV.

\section{Literature Review of Credible Threat}

The concept of credible threat can be revealed from the prisoner's dilemma. In infinitely repeated prisoner's dilemma model, partners' strategies will be taken at $t$ stage under the effect of $t-1$ stage. Due to the self-protection and the retaliation ability of partners, both of them will learn to cooperate and the game will reach the cooperative equilibrium. The inter-partner credible threat is "the certainty in either partner's retaliation to the other partner's earlier cheatings" (Zhang \& Rajagopalan, 2002). The transaction cost economic emphasizes on the use of internal organizational to preserve incentives to cooperate and share knowledge via controlling threats of opportunism (Sampson, 2004). Credible threat is one of the mechanisms to curb partners' opportunistic behavior and decrease related cost. As the concept of transaction cost theory, one's bounded rationality will limit his ability to cover all the possibilities in the contract. Incomplete contracting makes the firms vulnerable to the opportunistic behavior (Kaufmann, O'Neil \& York, 2006). Then, the present of credible threat is one of the useful tools to prevent bad behavior of partners.

Bergen, Heide and Dutta (1998) identified credible threat as the condition that increases the partners' enforcement abilities and decrease the other partners' bad behaviors that are costly to be detected. They indicated that the presence of an alternative channel of distribution in distributor's area is one form of credible threat, which can help manufacturers enhance their abilities to avoid distributors from violating established distribution. Zhang and Rajagopalan (2002) described that the presence of inter-partner credible threat can help partners to control the alliance and receive the payoff they deserved without being cheated. They obtained empirical evidence from four IJVs in China and figured out several factors that influence partners' credible threat. Kaufmann, O'Neil and York (2006) identified three mechanism to influence the stability of joint venture, including legal, economic and relationship mechanism. Credible threat belongs to the economic mechanism. The contracts can not always contain the entire possible situations; therefore, credible threat can play the role of extra-transactional dealing to prevent potential opportunistic behavior. They recognized that stopping transactions would be the source of credible threat and further examined the positive effect of credible threat on the survival of joint venture. The partner can retaliate by terminating other transactions that may be worth even more to the original party to prevent other partners' bad behaviors.

Cooperation builds upon the credible threat constitutes a self-enforcing equilibrium. This study argues that partners may possess unbalanced sources of credible threat and these unbalance sources between partners may result in their relative credible threat. Only a few researchers mentioned the determinants of inter-partner credible threat or examined the impact of the inter-partner credible threat (Zhang \& Rajagopalan, 2002; Duan \& Juma, 2007). Extending from the previous studies related to the inter-partner credible threat, this study develops an integrative determinants based on several dimensions including economic mechanism, business expertise and the relationship mechanism. Economic mechanism includes asset specificity and the investment size relative to the other partner. Technological capabilities, organizational capabilities and industrial experiences relative to the other partner are 
involved in business expertise, while behavioral transparency, dependency and dominant management relative to the other partner are discussed in relationship mechanism.

\section{Research Model and the Research Hypotheses}

\subsection{The Relationship between Economic Mechanisms and The Relative Credible Threat}

\subsubsection{Asset Specificity}

Asset specificity refers to the nonrecoverable and nonredeployable investment (Williamson, 1991). The decision a firm makes to invest nonrecoverable assets in IJV is risky because these assets, like sunk cost, redeployed to alternative uses lose or decrease their original productive value (Parkhe, 1993; Williamson, 1991). Therefore, firms suffer great financial risk (Kaufmann, O'Neil \& York, 2006). It will be costly for partners to terminate the cooperation because of the considerable switching cost. Owing to the potential loss of partners, high asset specificity represents the partners' credible commitment to the relationship and reduces the partners' opportunistic behavior (Parkhe, 1993; Kaufmann, O'Neil \& York, 2006) and partners are locked into the relationship, creating an exit barrier (Lui\& Ngo, 2005) and having no bargaining chips to threaten the other partners. They become loyal to the relationships and would not take horrible actions to destroy the team or even quit. There will be less credible threat the partners can exert on the others. Then, the dominant may force the other into making the bulk of the transaction-specific investment (Lonsdale, 2001). When the contribution of specific asset is asymmetric between partners, the partner who invests more specific asset may loss his bargaining power compared to other partners.

H1: The more specific asset one partner invests than the other, the less credible threat he can exert on the other partner.

\subsubsection{Investment Size}

Partner's investment in the IJV is an important financial source for IJV to operate. When the size of an IJV is large, it tends to be well diversified and is less likely to go bankrupt (Boateng, 2004). Large firms hold more resources than small and medium size firms (Beamish \& Lee, 2003) and large ventures can operate more stably, leading to better performance. Capital investment represents a key indicator of firm size and it is argued that the size of the investment could lead to partner's bargaining power. The asymmetric investment size would bring asymmetric partners' bargaining power. Partners with more bargaining power could be more influential in the IJV, so they may exert more credible threat as a result.

H2: The more investment size one partner invests than the other, the more credible threat he can exert on the other partner.

\subsection{The Relationship between Business Expertise and The Relative Credible Threat}

\subsubsection{Organizational Capability}

Organizational capability signifies a firm's ability to deploy resources, and to utilize resources for a desire end (Helfat \& Peteraf, 2003). Firms with organizational capabilities have better ability to control and handle the operation of business. Therefore, firms have stronger control are more influential on the overall operation of IJV. Powerful control and influence can also show the powerful punishment in the IJV. Yan and Gray (2001) suggested that an IJV parent can increase its control to curb opportunism by its partners. Better organizational capabilities can make partners more powerful and influential to control the IJV, and thus exert stronger punishment on the other partners. Therefore, partners with better organizational capabilities than others can better expose the others on the threat of powerful punishment.

H3: The better organizational capabilities one holds than the other partner, the more credible threat he can exert on the other.

\subsubsection{Technological Capability}

Technological capability refers to "the ability to develop and design new product and process and upgrade knowledge about the physical world in unique ways" (Wang, Lo, Zhang, \& Xue, 2006). Technology expertise is usually implicit in experiences and skills, firm-specific advantage (Lecraw, 1984). From the perspective of resource-based theory, capabilities, especially the technological skills, are hard to transfer and would bring forth competitive advantage for firms. Furthermore, many scholars have found the positive relationship between technological capabilities and business performance. Tsai (2004) identified technological capabilities as the most important determinant of a firm's productivity growth performance, which also had greater impact than other conventional factors, such as labors and physical capital. Wang et al. (2006) found that technological capabilities can increase a firm's ability to apply new external knowledge and directly result in better business performance and new product development performance. Once a partner contributes the key resources in the alliance and makes 
profit, the firm becomes powerful in the JV because the other partners would respond to his requests to prevent the absence of critical resources (Pfeffer \& Salanick, 1978). Therefore, a partner's technological capabilities will enhance his bargaining power. Yan and Gray (1994) found that the technological resources IJV partners bring to the table influenced the outcomes of the bargaining processes. Lecraw (1984) also argued that technology expertise was one of the sources of bargaining power which induces more control in the JV. The firm with more powerful technological capabilities will have more bargaining chips in the process of negotiation. The effects of actions the powerful partners take to punish the opportunistic behavior will be greater, so the threat they expose on the other partners will be quite influential. Therefore, if the contribution of technological capabilities is more asymmetric between partners, the bargaining power between partners would also be more unequal and the ability to exert credible threat would be more asymmetric.

H4: The more powerful technological capabilities one partner posses, the more credible threat one can exert on the other partner.

\subsubsection{Industrial Experience}

Kumar (1995) pointed out that firms with industrial experiences have the resource of knowledge, skills and learning capacity. In competitive markets, firms with abundant industrial experiences can be more adaptive to gain new technology and skills quickly and have competitive advantages. Industrial experience represents their market familiarity and is helpful for new product success (Nerkar \& Roberts, 2004). At the same time, industrial experience also represents the well-established important network with stakeholders and enterprises. Luo (1998) also indicated that partners' industrial experience demonstrated partners' history and strong background in the industry and often brought them good reputation and or high credibility in the market. Therefore, partners with long-length industrial experiences have their specific power and influence in the market. In addition, Luo (1997) found that partner's industrial experience had a significant effect on market growth and operation stability. Firms' accumulated experience and knowledge for years can better utilize proper methods to help the transaction be handled more efficiency and decrease operation cost. Base on these advantages, a firm with long-length industrial experiences can get certain bargaining power in alliances, and its network with other firms could be the punishment tool to avoid opportunistic behavior.

H5: The more industrial experiences one has than the other partner, the more credible threat he can exert on the other.

\subsection{The Relationship between Relationship Mechanisms And Partners'Relative Credible Threat}

\subsubsection{Low Dependency}

Alliances are formed when organizations perceive that they cannot achieve their desired outcomes through markets or hierarchies and can represent a configuration of interdependencies (Oliver, 1990). When the dependence between firms is high, both of them are critical to each other and cannot operate alliances alone. Gill and Butler (2003) argued that inter-partner dependence is a necessary condition for collaboration. Hennart (1988) recognized that when inter-partner dependency is high, it reduces the need for internal control within a joint venture. Parties can not escape from the relationship. Consequently, their behaviors are easier to be under control. Dependence favors alliance stability and provides a motivation to act in a trustworthy manner or promote a desire to resolve any conflicts (Gill \& Butler, 2003). However, if dependency is not symmetric between partners, the partner with lower dependency is more influential to the other because of his bargaining power. Therefore, when mutual dependency is more asymmetric, the partner with low dependency can exert more credible threat to the other.

H6: The more asymmetric between partners' dependency, the more credible threat one with less dependence can exert on the other.

\subsubsection{Behavioral Transparency}

Behavioral transparency means "the speed and reliability with which alliance partners learn about each other's actions" (Parkhe, 1993). When partners can easily learn and realize each other's behavior, their behavioral transparency is high. Eggert and Helm (2003) recognized that one's transparency could be perceived from the other's lens and is based on the perception of the information exchange and of the important characteristics of the interaction partner. According to the transaction cost theory, impacted information and uncertainty would increase transaction cost, including searching and monitoring cost. Bendor, Kramer and Stout (1991) noted that noise would vastly cause the monitoring problem and also affected the effectiveness of transaction. Transparency can help minimize the uncertainty and the need to constantly search for information (Eggert \& Helm, 2003). Parkhe (1993) suggested that partners' high behavioral transparency is helpful for cooperation. If one's behavior is very transparent, his behavior can be observed and monitored very directly and quickly; therefore, it decreases the transaction 
obstacle and cost for the others and it is efficient for the other partners to take reactions and execute subsequent strategies. Therefore, if the opportunistic behavior occurs, the partner can exert his punishment or retaliation very efficiently. In other words, when one's behavior is very opaque, the other is hard to react in time because there is observation lag. Therefore, if the behavior transparency is equal between partners, both of them can exert their credible threat equally efficiently.

H7: The more asymmetric between partners' behavior transparency, the one with low behavior transparency can exert more credible threat.

\subsubsection{Dominant Management}

Joint ventures are always prone to high transaction costs because of inter-partner negotiation cost (Kaufmann, O'Neil and York, 2006). Partners in alliance are always seeking for individual goal instead of alliance's goal; therefore, it raises a lot of cost of time and energy for partners to negotiate. Dominant management structure can minimize coordination cost and hence outperforms IJVs who shared control (Killing, 1983). Partners' dominant management usually represents by their more relative equity shares (Kaufmann, O'Neil \& York, 2006) or the share of management teams. The majority ownership may have greater power to detriment the other minority owner without negotiations (Yan \& Zeng, 1999). Lu and Hebert (2005) claimed that ownership control refers to the ability to exercise authority and influence over the IJV's strategic and operational decisions, systems and methods (Anderson \& Gatignon, 1986). Many scholars have agreed that dominant management is better to prevent partners' opportunism than shared control structure (Leraw, 1984; Killing, 1983; Ding, 1997), because firms with majority equity can utilize their legitimate authority to monitor operation of IJV and also punish the partners' bad behavior through voting rights. When the division of ownership is more asymmetric between partners, the dominator is more powerful to exert credible threat, which is stronger and more direct.

H8: The more dominant one's management is than the others, the more credible threat he can exert.

\section{Methods}

\subsection{Data Collection and The Sample}

Taiwanese companies engaging in IJV activities represent the population; the information was acquired from the website: http://newmops.tse.com.tw. As Burton and Saelens (1982) suggested, partners in the joint venture should possess at least $20 \%$ of equity shares. The study identified 419 eligible companies which engaged in IJV. After two mailing waves in 12 weeks, we received 52 responses, a $12.41 \%$ response rate. However, 12 responses were considered inappropriate as a result of incompleteness or over two partners in the partnership. Namely, 40 usable surveys were used to test our hypotheses. We tested these 40 usable responses for nonresponse bias by comparing early and late respondents; we find no evidence of nonresponse bias (Armstrong \& Overton, 1977).

\subsection{Measures}

Most of the questionnaire measurement items come from existing literature, anchored on seven-point Likert-type scales. Each questionnaire item of variables takes the form of comparison and the respondents are asked to compare the situation with his partner to understand the degree of difference between partners in IJV.

Regarding the dependent variable, we measure the inter-partner credible threat by asking whether the partner or the firm itself has ever taken opportunistic actions in this IJV, and whether the firm has relatively strong ability to punish the opportunistic behavior by the other partner when compared with the other partner. For the antecedents to inter-partner credible threat, we measure three dimensions which are economic mechanism, business expertise and relationship mechanism. We provide a detailed description of the measurement items in Table 1. Factor analysis (Hair, Anderson, \& Tatham, 1998) and the internal reliability statistics (Nunnally \& Bernstein, 1994) indicate a satisfactory level of content validity and reliability. Reliability values are all above 0.7 .

\subsection{Correlations and Hypothesis Tests}

We provide the description of the sample in Table 2 and the correlations among the variables in Table 3. Based on the research hypotheses, we develop the following regression equations:

$C_{i}=\beta_{0}+\beta_{1}$ asset specificity $+\beta_{2}$ investment size $+\beta_{3}$ organizational capabilities $+\beta_{4}$ technological capabilities $+\beta_{5}$ industrial experience $+\beta_{6}$ low dependency $+\beta_{7}$ behavioral transparency $+\beta_{8}$ dominant management $+\varepsilon$

Where $\mathrm{C}_{\mathrm{i}}$ refers to inter-partner credible threat and $\varepsilon$ represents random error. Regression analysis is used to measure the causality among variables and test the hypotheses. The result suggests that investment size in economic mechanism, technological capabilities in business expertise, and low dependency in relationship mechanism relate positively to credible threat. Therefore, Hypotheses 2, 3, and 6 are supported. In contrast, asset specificity in 
economic mechanism, organizational capabilities and industrial experiences in business expertise, and behavioral transparency and dominant management in relationship mechanism are not influential. Namely, Hypotheses 1, 4, 5 , 7 , and 8 are not supported.

\section{Discussion}

Investment size has a positive and significant effect on partners' relative credible threat entails that when a firm invests more capital compared to the other partner, the firm will be more powerful to exert his credible threat. The capital invested in the IJV makes the partner influential, turning to credible threat to avoid self-interest behavior. Financial assistance is substantiated to be the importance source of bargaining power and credible threat. Financial retaliation is helpful to punish bad behaviors per se.

Zhang and Rajagopalan (2002) found that the small local China partner can not exert credible threat to punish the opportunistic behavior of the Japanese partner because of the strategic importance of the specific asset investment. However, the result shows that asset specificity has a positive but not significant effect on partners' relative credible threat. The reason might be that firms with high specific investment have the sense of self-protection and would tend to use legal mechanism (e.g., contractual agreement) to avoid the perception of opportunistic behavior of partners. Legal protection is more important than mutual threat. As Table 2 depicts, $70 \%$ of the respondents indicate that they have five cooperative years with their partner before the IJV. The other possible reason might be that the partners have trust between each other. Since the asset specificity is the nonrecoverable and nonredeployable investment (Williamson, 1991), the investment of asset specificity represents their "credible commitment." The existence of trust would make firms to form alliances and invest their nonrecoverable asset. Therefore, the sense of trust makes credible threat less important. Partners might think it is not necessary to exert credible threat.

Technological capability is proved to have a positive effect on partners' relative credible threat. The result is in accordance with Zhang and Rajagopalan's (2002) finding which indicated that technological capability is one of the sources of credible threat between partners. The other two variables, organizational capabilities and industrial experiences, produce insignificant effects. Technology know-how tends to be the stronger weapon in IJV credible threat than the management, process know-how and experience. Overall, business expertise has been viewed as the important source of bargaining power; however, the results show that not all of the bargaining chips can turn to be the punishing tool and prevent partners' opportunistic behaviors. The possible reasons come from the external and internal environment, such as contractual rigidity, trust and partners' subjective will. On the other hand, due to the contractual rigidity, partners' specific abilities are required to execute under the contractual stipulations.

Abundant research indicated that the relationship between partners in an IJV is considered crucial. According to the relationship mechanism, low dependency is proved to have a positive effect on inter-partner credible threat. A less dependent partner tends to be more flexible and self efficient in a collaboration. On the other hand, it also indicates that a highly dependent firm will stick to the cooperation, making the firm less powerful in negotiation.

Finally, dominant management and behavioral transparency are not influential. The problem is that in the absence of an historical relationship between the partners, in which trust has been developed, determining a potential partners' inclination toward opportunism is reduced. As noted above in Table 2, 70\% of the respondents indicate that they have more than five years of cooperation with their partners before the IJV and $60 \%$ of the respondents reveal that their IJV experience with partners are more than five years. Trust reduces the problem for a party to signal to its partner. The level of perceived trust instead of transparency should lessen the need for costly mechanisms to guard against opportunism. IJVs are prone to high transaction costs due to inter-partner negotiations. Costs arise from the time and energy involved in frequent negotiations and co-management conflict. The effect of dominant management is mixed (Choi \& Beamish, 2004). The detrimental impact of inter-partner negotiation can be reduced by agreeing to decide the responsibility in advance, regardless of dominant or shared management. In addition, partners might not punish every opportunistic behavior in the IJV as long as such behavior would not be too serious to make IJV unstable. In partners' toleration zone, firm might reduce the conflict and negotiation in management. The exertion of punishment might cost time, efforts and even cause possible losses.

\section{Conclusion}

In this study, we identify the criteria of credible threat and explore if asymmetric source would cause partners' relative credible threat. We found some implications. First, credible threat is dynamic. It is argued that the main source of credible threat is derived from partners' bargaining power. As Yan and Gray (1994) discussed, bargaining power is dynamic and transferrable. The power of bargainer will differ when internal and external environment change. It is suggested that a firm needs to enhance its capabilities to maintain its influence and importance in the alliance. Second, firms should enhance their input of critical and imperfect imitable resources. As our results show, firms with technology capability and large investment size relative to the other partner have positive influence on 
their relative inter-partner credible threat. More monetary investment makes IJV diversified and stable (Boateng, 2004). Therefore, the size of investment can enhance partners' position in the IJV and better control the alliances (Steensma \& Lyles, 2000). A firm with dominant investment size becomes the source of inter-partner credible threat and has control over the IJV. Thus, enhancing the input of critical and imperfect imitable resources (e.g., capital and technology) can be the tool to threaten and punish the opportunistic partners. Third, firms need to keep the contract specific and contingent. It is argued that one of the reason partners are unable to exert their credible threat is because of contractual incompleteness and rigidity. Thus, it is suggested that the relational contract should be as completive as possible. Finally, firms should choose their partners carefully before the cooperation. Firms may not always monitor and punish their partners' opportunistic behaviors, even if they have the inter-partner credible threat to their partners. For corporations, searching new partners might be more annoying, incurring time, effort and switching cost. Therefore, firms tend to tolerate partners' opportunistic behaviors, as long as the opportunistic behavior would not cause too much loss.

Certain limitations are of note in this study. First, the low response rate and small sample size represent the major limitation. Apparently, the small sample size impedes generalization of the results. Second, we did not control extraneous effects in this study. Likewise, the study assumes normality, linearity, independence of error term, free from multicollinearity, etc in the regression analysis; these assumptions need further confirmation. Particularly, this study is the first to attempt to test the antecedents to inter-partner credible threat. Prior research largely focuses on the IJV's survival or payoff under inter-partner credible threat. Thus, future studies exploring other factors affecting inter-partner credible threat and/or considering the IJV's performance are suggested.

\section{References}

Anderson, E., \& Gatignon, H. (1986). Modes of entry: a transaction cost analysis and propositions. Journal of international Business Studies, 17(3), 1-26. http://dx.doi.org/10.1057/palgrave.jibs.8490432

Armstrong, J. S., \& Overton, T. S. (1977). Estimating non-response bias in mailing surveys. Journal of Marketing Research, 14 (August), 396-402. http://dx.doi.org/10.2307/3150783

Beamish, P. W., \& Lee, C. (2003). The Characteristics and Performance of Affiliates of Small and Medium-Size Multinational Enterprises in an Emerging Market. Journal of International Entrepreneurship, 1(1), 121-134. http://dx.doi.org/10.1023/A:1023223424789

Beamish, P. W., \& Jung, J. C. (2005). The performance and survival of joint ventures with parents of asymmetric size. Management International, 10(1), 19-30. http://cat.inist.fr/?aModele=afficheN\&cpsidt=17555819

Bendor, J., Kramer, R. M., \& Stout, S. (1991). When in doubt? Cooperation in a noisy prisoner's dilemma. Journal of Conflict Resolution, 35(4), 691-719. http://dx.doi.org/10.1177/0022002791035004007

Bergen, M., Heide, J. B., \& Duta, S. (1998). Managing gray markets though tolerance of violations: a transaction cost. Managerial and Decision Economics, 19(3), 157-165. https://www.csom.umn.edu/Assets/71546.pdf.

Blodgett, L. (1992). Factors in the instability of international joint ventures: an event history analysis. Strategic Management Journal, 13(6), 127-135. http://dx.doi.org/10.1002/smj.4250130607

Boateng, A. (2004). Determinants of capital structure - Evidence from international joint ventures in Ghana. International Journal of Social Economic, 31(1/2), 56-66. http://dx.doi.org/10.1108/03068290410515411

Burton, F. N., \& Saelens, F. H. (1982). Partner choice and linkage characteristics of International Joint Ventures in Japan: an exploratory analysis of the inorganic chemicals sector. Management International Review, 2(22), 1-21. http://www.jstor.org/pss/40227632.

Choi, C., \& Beamish, P. W. (2004). Split management control and international joint venture performance. Journal of International Business Studies, 35(3), 201-215. http://dx.doi.org/10.1057/palgrave.jibs.8400078

Day, G. S., (1994). The capabilities of the market-driven organization. Journal of Marketing, 58, 37-52. http://www.jstor.org/stable/1251915.

Delios, A., \& Beamish, P. W. (1999). Ownership strategy of Japanese firms: transactional, institutional and experience influences. Strategic Management Journal, 20(10), 915-933. http://dx.doi.org/10.1002/(SICI)1097-0266(199910)20:10<915::AID-SMJ51>3.0.CO;2-0.

Ding, D. Z. (1997). Control, Conflict, and Performance: a study of US-Chinese joint ventures. Journal of International Marketing, 31-45. http://www.scopus.com/record/display.url?eid=2-s2.0-0002744218\&origin=inward\&txGid=HPM2y30t-rOoRYJGEJ du1nh\%3a2. 
Duan, J., \& Juma, N. (2007). Inter-partner credible threat and the survival of U.S.-China joint ventures. Journal of Business Strategies, 24(1), 91-104. http://www.freepatentsonline.com/article/Journal-Business-Strategies/165017898.html.

Eggert, A., \& Helm, S. (2003). Exploring the Impact of relationship transparency on business relationships: A cross-sectional study among purchasing managers in Germany. Industrial Marketing Management, 32(2), 101-108. http://dx.doi.org/10.1016/S0019-8501(02)00224-9

Frazier, G.. L. (1983). On the Measurement of Interfirm Power in Channels of Distribution. Journal of Marketing Research, 20(2), 158-166. http://www.jstor.org/stable/3151682.

Freeman, R. E. (1987). Review of the economic institutions of capitalism by O. E. Williamson. Academy of management Review, 385-387. http://connection.ebscohost.com/c/book-reviews/4308003/economic-institutions-capitalism.

Frideman, D., \& Hechter, M. (1990). The comparative advantage of rational choice theory. In G. Ritzer, Frontiers of social theory. The New York: Columbia University Press.

Ganesan, S. (1994). Determinants of long-term orientation in buyer-seller relationships. Journal of Marketing, 58, 1-19. http://www.jstor.org/stable/1252265.

Gill, J., \& Butler, R. (2003). Managing Instability in Cross-Cultural Alliances. Long Range Planning, 36(6), 543-563._http://dx.doi.org/10.1016/j.lrp.2003.08.008

Gulati, R., Khanna, T., \& Nohria, N. (1994). Unilateral Commitment and the importance of Process in Alliances. Sloan Management Review, 35(3), 61-69. http://search.proquest.com/docview/224964530.

Hair, J., Anderson, R., \& Tatham, R. (1998). Multivariate data analysis. Englewood Cliffs, NJ: Prentice-Hall.

Helfat, C. E., \& Peteraf, M. A. (2003). The dynamic resource-based view: capability lifecycles. Strategic Management Journal, 24(10), 997-1010. http://dx.doi.org/10.1002/smj.332

Hennart, J. (1988). A Transaction costs theory of equity joint venture. Strategic Management Journal, 9(4), 361-374. http://dx.doi.org/10.1002/smj.4250090406

Kaufmann, J., O’Neill, H. M., \& York, A. S. (2006). The impact of structural prescriptions on joint venture survival. American Journal of Business, 21(2), 43-60. http://dx.doi.org/10.1108/19355181200600009

Killing, J. P. (1983). Strategies for Joint venture Success. New York: Praeger Publishers.

Kumar, B. N. (1995). Partner-selection criteria and success of technology transfer: A Model based on learning theory applied to the case of Indo-German technical collaborations. Management International Review, 35(1), 65-78. http://www.jstor.org/stable/40228296

Lado, A., Boyd, N. G., \& Wright, P. (1992). A competency-based model of sustainable competitive advantage: toward a conceptual integration. Journal of Management, 18(1), 77-91. http://dx.doi.org/10.1177/014920639201800106

Lane, P., Salk, J. E., \& Lyles, M. A. (2001). Absorptive capacity, Learning and Performance in International Joint ventures. Strategic Management Journal, 22(12), 1139-1161. http://dx.doi.org/10.1002/smj.206

Lecraw, D. J. (1984). Bargaining power, ownership, and profitability of transnational corporations in developing countries. Journal of International Business Studies, 15, 27-43. http://www.jstor.org/pss/154555.

Lin, X. (2004). Determinations of culture adaptation in Chinese-U.S. joint venture. Cross Cultural Management: An International Journal, 11(1),35 - 47. http://dx.doi.org/10.1108/13527600410797738

Lonsdale, C. (2001). Lock-in to Supplier Dominance: On the Dangers of Asset specificity for the Outsourcing Decision. Journal of Supply Chain Management, $37(2), \quad 27$. http://www.freepatentsonline.com/article/Journal-Supply-Chain-Management/75142125.html.

Lu, J. W., \& Hebert, L. (2005). Equity control and the survival of international joint ventures: a contingency approach. Journal of Business Research, 58, 736-745. http://dx.doi.org/10.1016/j.jbusres.2003.08.012

Lui, S. S., \& Ngo, H. (2005). The influence of structural and process factors on partnership satisfaction in interfirm cooperation. Group Organization Management, 30(4), 378-397, http://dx.doi.org/10.1177/1059601103259113

Luo, Y. (1997). Partner selection and venturing success: the case of joint venture with firms in the People's Republic of China. Organization Science, 8(6), 648-662. http://www.jstor.org/stable/2635161

Luo, Y. (1998). Joint venture success in China: how should we select a good partner? Journal of World Business, 


\section{3(2), 145-166. http://dx.doi.org/10.1016/S1090-9516(98)90003-7}

Madhok, A. (2006). How much does ownership really matter? Equity and trust relations in joint venture relationships. Journal of International Business Studies, $37(1), \quad 4-11$. http://dx.doi.org/10.1057/palgrave.jibs.8400182

Meschi, P. (2005). Environmental uncertainty and survival of international joint venture: the case of political and economic risk in emerging countries. European Management Review, 2, 143-152. http://dx.doi.org/10.1057/palgrave.emr.1500037

Nerkar, A., \& Roberts, P. W. (2004). Technological and product-market experience and the success of new product introductions in the pharmaceutical industry. Strategic Management Journal, 25(8/9), 779-799. http://dx.doi.org/10.1002/smj.417

Nunnally, J. C., \& Bernstein, I. H. (1994). Psychometric theory. (3rd ed.) New York: McGraw-Hill.

Oliver, C. (1990). Determinants of inter-organizational relationship: Integrat. The Academy of Management Review, 15(2), 241-265. http://www.jstor.org/pss/258156.

Parkhe, A. (1993). Strategic alliance structuring: a game theoretic and transaction cost examination of interfirm cooperation. Academy of Management Journal, 36(4), 794-829. http://www.jstor.org/pss/256759.

Pearce, R. J. (1997). Toward understanding joint venture performance and survival: a bargaining and influence approach to transaction cost theory. Academy of Management Review, 22(1), 203-225. http://www.jstor.org/pss/259229.

Pfeffer, J., \& Salanick, G. R. (1978). The external control of organization. New York: Harper and Row.

Sampson, R. C. (2004). Organizational choice in R\&D alliances: knowledge-based and transaction cost perspectives. Managerial and Decision Economics, 25, 421-436. http://dx.doi.org/10.2139/ssrn.424100

Saxton, T. (1997). The effects of partner and relationship characteristics on alliance outcomes. Academy of Management Journal, 40(2), 443-461. http://www.jstor.org/pss/256890

Steensma, H. K., \& Lyles, M. A. (2000). Explaining IJV survival in a transitional economy through social exchange and knowledge-based perspectives. Strategic Management Journal, 21(8), 831-851. http://dx.doi.org/10.1002/1097-0266(200008)

Teece, D. J., Pisano, G., \& Shuen, A. (1997). Dynamic capabilities and strategic management. Strategic Management Journal, 18(7), 509-533. http://dx.doi.org/10.1002/(SICI)1097-0266(199708)

Tsai, K. (2004). The impact of technological capability on firm performance in Taiwan's electronics industry. The Journal of High Technology Management Research, 15(2), 183-195. http://dx.doi.org/10.1016/j.hitech.2004.03.002

Wang, Y., Lo, H., Zhang, Q., \& Xue, Y. (2006). How technological capability influences business performance: an integrated framework based on the contingency approach. Journal of Technology Management in China, 1(1), 27-52. http://dx.doi.org/10.1108/17468770610642740

Williamson, O.E. (1985). The Economic Institutions of Capitalism. New York: Free Press.

Williamson, O. E. (1991). Markets and Hierarchies. New York: Free Press.

Yan, A., \& Gray, B. (1994). Bargaining power, management control, and performance in United States-China joint venture: a comparative case study. Academy of Management Journal, 37(6), 1478-1517. http://dx.doi.org/10.2307/256796

Yan, A., \& Gray, B. (2001). Negotiating control and achieving performance in international joint ventures: a conceptual model. Journal of International Management, 7(4), 295-315. http://dx.doi.org/10.1016/S1075-4253(01)00049-7

Yan, A., \& Zeng, M. (1999). International joint venture instability: a critique of previous research, a reconceptualization, and directions for future research. Journal of International Business Studies, 30(2), 397-414. http://dx.doi.org/10.1057/palgrave.jibs.8490076

Zhang, Y., \& Rajagopalan, N. (2002). Inter-partner credible threat in international joint venture: an infinitely repeated prisoner's dilemma model. Journal of International Business Studies, 33(3), 457-478. http://dx.doi.org/10.1057/palgrave.jibs.8491026 
Table 1. Variable Operational Definition, Questionnaire Items

\begin{tabular}{|c|c|c|c|}
\hline Variables & Operational definition & Questionnaire items & Reference \\
\hline \multicolumn{4}{|c|}{ Economic mechanism } \\
\hline Asset -specificity & $\begin{array}{l}\text { The degree to which an asset can be redeployed to } \\
\text { alternative uses and by alternative users without } \\
\text { sacrifice of productive value. }\end{array}$ & $\begin{array}{l}\text { 1. degree to change firms' way of wording to suit } \\
\text { needs of IJV } \\
\text { 2. degree to investment in time and effort for this } \\
\text { project } \\
\text { 3. degree they waste knowledge concerning each } \\
\text { other's methods of operation if partners decided to } \\
\text { stop working with each other } \\
\text { 4. advertising intensity } \\
\text { 5. R \& D intensity }\end{array}$ & $\begin{array}{l}\text { Delios } \\
\& \text { Beamish, } \\
\text { 1999; } \\
\text { Lui \& Ngo, } \\
2005\end{array}$ \\
\hline Investment size & Partners' relative capital amount of investment & $\begin{array}{l}\text { total capital amount of investment relative to the } \\
\text { other partner }\end{array}$ & \\
\hline \multicolumn{4}{|l|}{ Business expertise } \\
\hline $\begin{array}{l}\text { Organizational } \\
\text { capability }\end{array}$ & Organizational and managerial process & $\begin{array}{l}\text { 1. managerial competencies } \\
\text { 2. knowledge and skills of employees } \\
\text { 3. firm climate } \\
\text { 4. organizational structure } \\
\text { 5. coordination } \\
\text { 6. strategic planning } \\
\text { 7. ability to attract creative employees }\end{array}$ & $\begin{array}{l}\text { Teece et. al, } \\
1997\end{array}$ \\
\hline $\begin{array}{l}\text { Technological } \\
\text { capability }\end{array}$ & those that develop and produce technology & $\begin{array}{l}\text { 1. technology development capabilities } \\
\text { 2. manufacturing processes } \\
\text { 3. new product development capabilities } \\
\text { 4. technological capabilities } \\
\text { 5. manufacturing and plant equipment }\end{array}$ & $\begin{array}{l}\text { Day ,1994; } \\
\text { Lado et } \\
\text { al. ,1992 }\end{array}$ \\
\hline $\begin{array}{l}\text { Industrial } \\
\text { experience }\end{array}$ & IJV industrial experience & $\begin{array}{l}\text { partners' industrial involving years relative to the } \\
\text { other partner }\end{array}$ & \\
\hline \multicolumn{4}{|c|}{ Relationship mechanism } \\
\hline Low dependency & $\begin{array}{l}\text { Partner's need to maintain the alliance } \\
\text { relationship with the other to achieve desired } \\
\text { goals }\end{array}$ & $\begin{array}{l}\text { 1. firm has strong power than the other partner } \\
\text { 2. firm has strong influence than the other partner } \\
\text { 3. Reliance or the dependency on the partner } \\
\text { (reverse coded) }\end{array}$ & $\begin{array}{l}\text { Lin, } 2004 \\
\text { Ganesan, } 1994\end{array}$ \\
\hline $\begin{array}{l}\text { Behavioral } \\
\text { transparency }\end{array}$ & $\begin{array}{l}\text { the speed and reliability with which alliance } \\
\text { partners learn about each other's actions }\end{array}$ & $\begin{array}{l}\text { 1. Information source. } \\
\text { 2. Information accuracy. } \\
\text { 3. Speed to get information. }\end{array}$ & Parkhe, 1993 \\
\hline $\begin{array}{l}\text { Dominant } \\
\text { management }\end{array}$ & the division of equity between partners & $\begin{array}{l}\text { the division of equity shares and the top } \\
\text { management team with the other partner }\end{array}$ & Blodgett, 1992 \\
\hline
\end{tabular}


Table 2. Description of the sample

\begin{tabular}{|c|c|c|c|c|}
\hline Variables & Classification & Frequency & Percent $(\%)$ & Cumulative percent \\
\hline \multirow[t]{4}{*}{ Amount of capital investment } & Below 2 billion & 20 & $50 \%$ & $50 \%$ \\
\hline & $2-6$ billion & 10 & $25 \%$ & $75 \%$ \\
\hline & 6-10billion & 2 & $5 \%$ & $80 \%$ \\
\hline & Over 10 billion & 8 & $20 \%$ & $100 \%$ \\
\hline \multirow{4}{*}{$\begin{array}{l}\text { Total profit } \\
\text { (last year) }\end{array}$} & Below 2 billion & 10 & $25 \%$ & $25 \%$ \\
\hline & $2-6$ billion & 15 & $37.5 \%$ & $62.5 \%$ \\
\hline & 6-10billion & 3 & $7.5 \%$ & $70 \%$ \\
\hline & Over 10 billion & 12 & $30 \%$ & $100 \%$ \\
\hline \multirow[t]{4}{*}{ Number of employee } & Below 1000 & 26 & $65 \%$ & $65 \%$ \\
\hline & $1000-2000$ & 5 & $12.5 \%$ & $77.5 \%$ \\
\hline & $2000-3000$ & 4 & $10 \%$ & $87.5 \%$ \\
\hline & Over 3000 & 5 & $12.5 \%$ & $100 \%$ \\
\hline \multirow[t]{3}{*}{ Years of firms } & Below 15 years & 4 & $10 \%$ & $10 \%$ \\
\hline & $15-25$ years & 4 & $10 \%$ & $20 \%$ \\
\hline & Over 25 years & 32 & $80 \%$ & $100 \%$ \\
\hline \multirow[t]{3}{*}{ Years of investment overseas } & Below 15 years & 25 & $62.5 \%$ & $62.5 \%$ \\
\hline & $15-25$ years & 11 & $27.5 \%$ & $90 \%$ \\
\hline & Over 25 years & 4 & $10 \%$ & $100 \%$ \\
\hline \multirow[t]{3}{*}{ Years of IJV } & Below 5 years & 16 & $40 \%$ & $40 \%$ \\
\hline & $5-15$ years & 21 & $52.5 \%$ & $92.5 \%$ \\
\hline & $15-25$ years & 3 & $7.5 \%$ & $100 \%$ \\
\hline \multirow{4}{*}{$\begin{array}{l}\text { Partners' cooperative years } \\
\text { (Before IJV) }\end{array}$} & Below 5 years & 12 & $30 \%$ & $30 \%$ \\
\hline & $5-15$ years & 16 & $40 \%$ & $70 \%$ \\
\hline & $15-25$ years & 4 & $10 \%$ & $80 \%$ \\
\hline & Over 25 years & 8 & $20 \%$ & $100 \%$ \\
\hline
\end{tabular}

Table 3. Pearson correlation Analysis Result

\begin{tabular}{lccccccccc}
\hline Variables & Mean & S.D. & 1 & 2 & 3 & 4 & 5 & 6 & 7 \\
\hline 1.Asset Specificity & 4.112 & 1.168 & & & & & & \\
2.Investment Size & 2.775 & 2.455 & $-.467^{\mathrm{c}}$ & & & & & & \\
3.Organizational Capabilities & 5.329 & 0.964 & .014 & .082 & & & & & \\
4.Technological Capabilities & 4.38 & 1.722 & .024 & -.087 & .062 & & & & \\
5.Industrial Experience & 3.025 & 2.496 & -.132 & $.341^{\mathrm{b}}$ & .122 & .094 & & & \\
6.Low Dependency & 4.575 & 1.408 & -.005 & -.012 & .021 & .058 & .176 & & \\
7.Behavior Transparency & 4.7 & 1.4 & .02 & .057 & -.039 & -.034 & -.106 & -.053 & \\
8.Dominant Management & 1.675 & 2.566 & -.087 & .043 & .079 & .246 & .051 & $.369^{\mathrm{b}}$ & $.333^{\mathrm{a}}$ \\
9.Credible Threat & 4.175 & 1.708 & -.145 & $.372^{\mathrm{b}}$ & .14 & .285 & .106 & $.38^{\mathrm{b}}$ & .161 \\
\hline
\end{tabular}

Note: ${ }^{\text {a }} \mathrm{P}<.10 ;{ }^{\mathrm{b}} \mathrm{P}<.05 ;{ }^{\mathrm{c}} \mathrm{P}<.01$ 
Table 4. Regression Result of the Relationship between economic mechanism, business expertise, relationship mechanism and the inter-partner credible threat

\begin{tabular}{llll}
\hline \multicolumn{3}{c}{ Inter-partner Credible threat } & \\
\hline Variables & Model 1 & Model 2 & Model 3 \\
\hline 1.Asset specificity & $0.019(0.112)$ & $0.024(0.142)$ & $0.030(0.196)$ \\
2.Investment size & $0.379(2.223)^{* *}$ & $0.390(2.206)^{* *}$ & $0.415(2.530)^{* *}$ \\
3.Organizational capabilities & & $0.176(1.173)$ & $0.163(1.165)$ \\
4.Technological capabilities & & $0.301(2.023)^{*}$ & $0.254(1.803)^{*}$ \\
5.Industrial experience & & $-0.004(-0.023)$ & $-0.132(-0.859)$ \\
6. Low dependency & & & $0.356(2.315)^{* *}$ \\
7.Behavioral transparency & & & $-0.190(-1.279)$ \\
8.Dominant management & & & $0.125(0.768)$ \\
& 0.138 & 0.241 & 0.419 \\
R2 & 0.091 & 0.129 & 0.269 \\
Adjusted R & $2.95^{*}$ & $2.157^{*}$ & $2.790^{* *}$ \\
F & & & \\
\hline
\end{tabular}

Note: $*$ : $<<0.05 ;{ }^{* *}: \mathrm{p}<0.01$; $^{* * *} \mathrm{p}<0.001$

Standardized path estimate ( $\mathrm{t}$ value)

\section{Economic Mechanisms}

Asset Specificity

Investment Size

Business Expertise

Organizational Capabilities

Technological Capabilities

Industrial Experiences

Relationship Mechanisms

Low Dependency

Behavior Transparency

Dominant management

Figure 1. Research Framework 